Збірник наукових прачь Державного науково-дослідного інституту випробувань і сертифікачії озброєння та військової техніки. 2019. Вип. № 2

Башинський В.Г., Телевний І.В., Нікітченко В.І. Державний науково-дослідний інститут випробувань і сертифікації озброєння та військової техніки

\title{
МЕТОДИЧНИЙ ПІДХІД ЩОДО ВИЗНАЧЕННЯ ВЕЛИЧИНИ ЗБИТКУ ВІЙСЬКАМ ПРОТИВНИКА ШТУРМОВОЮ АВІАЦІЕЮ 3 УРАХУВАННЯМ ЕФЕКТИВНОСТІ ЗАСТОСУВАННЯ АВІАЦІЙНИХ ЗАСОБІВ УРАЖЕННЯ
}

\begin{abstract}
У статті запропоновано методичний підхід щеодо визначення величини збитку військам (об'єктам) противника, щзо прикриваються угрупуваннями військ протиповітряної оборони, итурмовою авіацією 3 урахуванням ефективності авіаційних засобів ураження та методичний підхід для ефективного дослідження стохастичних властивостей застосування авіаційних засобів ураження по наземним иілям. Проведено аналіз наземних типових иілей та визначено, щзо переважна більшість иілей являють собою розосереджені на деякій площзі об’єкти. Визначено основні калібри, які застосовуються штурмовою авіацією для нанесення збитку об'єктам противника. Підтверджено, щуо найбільш повним показником оцінки ефективності нанесення збитку наземним об’єктам, щз прикриваються угрупуваннями військ протиповітряної оборони, авіацією, можна вважати математичне очікування величини збитку нанесеного авіачією об'єктам і враховує головні завдання авіації по знищенню об’єктів, ефективність застосування авіаційних засобів ураження штурмовою авіацією та важливість даних об'єктів.
\end{abstract}

Ключові слова: ймовірність ураження, величина збитку, типові иүілі, итурмова авіація.

\section{Постановка проблеми}

Основною метою повітряного нападу штурмової авіації на наземні війська (об’єкти) є нанесення максимального збитку військам (об’єктам) противника, що прикриваються угрупуваннями військ протиповітряної оборони (ППО).

У ході повітряного нападу вирішуються завдання ефективного використання засобів повітряного нападу [1].

Тому, виникає необхідність визначення величини збитку в результаті повітряного нападу 3 врахуванням ефективності авіаційних засобів ураження та збереження максимальної кількості літальних апаратів.

\section{Аналіз останніх досліджень і публікацій}

В [2] розглянуті питання ефективного подолання системи ППО, що прикривають угрупування військ (об'єктів). Для оцінки ефективності системи ППО використовується такий показний, як математичне очікування відвернутого збитку нанесеного наземним цілям, що прикриваються угрупуваннями військ ППО, авіацією. Для визначення ефективності штурмової авіації по наземним об'єктам доцільно враховувати ще й такий показник, як ефективність авіаційних засобів ураження (АЗУ). У статті розглянуто питання методичного підходу щодо визначення величини збитку в результаті повітряного нападу штурмової авіації з урахуванням ефективності АЗУ.

\section{Виклад основного матеріалу}

На сьогоднішній день, групові наземні цілі, що являють собою сукупність розосереджених на місцевості цілей, є одними з основних наземних цілей, для ураження яких застосовуються АЗУ [3].

До таких цілей відносяться: РЛС, засоби радіозв’язку, пускові установки з встановленими на них ракетами різного класу, літаки та вертольоти на відкритих стоянках (обвалуваннях), транспортні вузли, командні пункти в легких укриттях, відкриті склади різного призначення, війська і бойова техніка на відкритій стоянці та в укриттях легкого типу, одноповерхові (двоповерхові) виробничі будинки і будівництва міського типу, лінії електропередач, нафто- газопроводи незаглиблені у грунт, бронетранспортери, бойові машини піхоти, контейнерні пускові установки. 
АЗУ застосовуються по широкій номенклатурі наземних цілей. За характеристиками уразливості всі наземні цілі підрозділяються на такі основні групи:

- легкоуразливі цілі (поразка яких еквівалентна пробиттю дюралевої пластини товщиною 15 мм, стальної - 6 мм).;

- легкоброньовані цілі (еквівалентом є сталеві пластини товщиною до 20 мм);

- броньовані цілі (з потужним броньовим захистом - до 200 мм);

- бетоновані цілі (ураження досягається за рахунок руйнації або пробиття масивних бетонних і залізобетонних перекриттів);

- цегляні (залізобетонні) будівлі міського типу і захищені цілі, які можна розділити на напівпідземні, підземні та заглиблені.

Для кожної групи цілей з урахуванням їхньої вразливості доцільно застосовувати такі АЗУ, що володіють відповідним видом уражаючої дії.

Легкоуразливі цілі ефективно уражаються фугасною, осколочною, кумулятивною i запальною дією АЗУ. Ефективне ураження легкоброньованих досягається за рахунок тих же видів уражаючої дії, що і легкоуразливі цілі. Але параметри АЗУ повинні забезпечувати необхідне пробиття перепон. Цілі 3 броньованим захистом уражаються за рахунок дії кумулятивного струменя, що проникає за броню. Цілі, що мають бетонні і залізобетонні перекриття, найбільш ефективно уражаються бетонобійною (проникаючою) і фугасною дією товстостінних АЗУ.

Як показує аналіз характеристик сучасних наземних цілей, для ураження яких застосовуються АЗУ, найбільш поширеними є групові наземні цілі, що являють собою сукупність розосереджених на місцевості цілей.

Аналіз використання АЗУ авіацією по наземних об'єктах у військових конфліктах у Перській затоці, Югославії, Іраку та АТО дозволяє привести таку класифікацію об'єктів, що уражуються (за термінологією НАТО):

- об’єкти систем керування та зв’язку стратегічної ланки;

- об'єкти системи ППО;

- об'єкти зберігання паливно-мастильних матеріалів;

- об'єкти забезпечення діяльності силових структур;

- лінії комунікацій;

- війська.

Аналіз показує, що частка легкоуразливих та легкоброньованих цілей із загальної їх кількості, уражених під час військових конфліктів у Перській затоці, Югославії та Іраку, складає біля 80\%, та біля 20\% від загальної кількості складають броньовані, бетоновані і сильнозахищені наземні цілі.

Проаналізувавши калібри АЗУ, що були застосовані при локальних військових конфліктах для ураження легкоуразливих та легкоброньованих цілей штурмовою авіацією, можна виділити калібри АЗУ, що найпоширеніше застосовувалися для ураження даних типів цілей. Такими калібрами є 250 та 500 кг. Дані калібри є основними калібрами, які застосовуються штурмовою авіацією для нанесення збитків об’єктам противника.

При проведенні оцінки ефективності дані цілі можна представити у вигляді деякої геометричної площини, на якій розміщені розосереджені на місцевості елементарні цілі та, яка лежить у площині поверхні землі. А при математичних розрахунках доцільно враховувати не всю геометричну площину, а лише приведену площу, при влучанні в яку уражаючого елементу АЗУ елементарна ціль вважаться ураженою з ймовірністю не менше заданої.

У більшості розосереджених на місцевості цілей не вся приведена площа однаково відповідає за функціональну приналежність об'єкту. Так, наприклад, при розміщенні батареї ЗРК за функціонування позиції, як об'єкту протиповітряної оборони, “відповідають” радіолокаційні станції (РЛС) [4], виведення з ладу яких призводить до неможливості виявлення цілей та проведення стрільби зенітними керованими ракетами. 
Тому, при застосуванні АЗУ по розосередженим на місцевості цілям доцільно уражати не всю приведену площу, а лише ту іiі частину, що відповідає за функціонування всього об'єкту.

Характеристики основних типових розосереджених цілей наведені нижче.

Мотопіхотний батальйон складається із штабної роти, трьох мотопіхотних рот та роти вогневої підтримки, який у районі розосередження займає площу $2 \ldots 3$ х $3 \ldots 4$ км, маючи проміжки між ротами $1 \ldots 1,5$ км, рота розташовується на площі 400 х $500 \ldots 700$ м, взвод займає площу $150 \ldots 200$ x $100 \ldots 150$ м.

У якості типових ЗРК великої та середньої дальності розглянемо ЗРК “НайкГеркулес" й "Петріот". ЗРК великої дальності “Найк-Геркулес" призначений для ураження одиночних та групових повітряних цілей, що летять на висотах 1,5..30 км і дальностях $11 \ldots 160$ км. Організаційно ЗРК “Найк-Геркулес" зведені в дивізіони, кожен з яких включає в себе 4 батареї. Позиція батареї ЗРК “Найк-Геркулес” займає площу з розмірами $1700 \ldots 200$ м х 1000...1500 м. Батарея перестає функціонувати як об’єкт ПВО при виводі з ладу: усіх пускових установок або апаратури керування ними, РЛС спостереження за ціллю або РЛС спостереження за снарядом, апаратури керування вогнем батареї, енергоагрегатів, що забезпечують роботу елементів батареї. Найбільш уразливими елементами батареї $є$ антенні агрегати РЛС. Антенні системи і апаратура розміщуються на площі розмірами 250м х 350м.

ЗРК “Петріот” призначений для ураження літаків і балістичних ракет оперативнотактичного призначення на висотах до 30 км, дальність стрільби складає в межах $4 \ldots 75$ км [4]. Дивізіон ЗРК "Петріот" складається із шести вогневих секцій, які попарно зведені в три батареї. Вогнева секція має в своєму складі пункт управління вогнем та зв'язку, багатофункціональну РЛС, енергоблок та п'ять пускових установок контейнерного типу по чотири ракети в кожній. Позиція вогневої секції ЗРК “Петріот” розташована на площі розмірами $1000 \ldots 1200$ м х $600 \ldots 800$ м. Вогнева секція перестає функціонувати при виводі 3 ладу багатофункціональної РЛС, енергоблоку або пункту управління вогнем. Найбільш уразливими елементом вогневої секції ЗРК “Петріот” $є$ багатофункціональна РЛС, що розміщуються на площі розмірами 200 м х 300 м [5].

Польовий склад може мати розміри від $150 . .200$ м х $200 \ldots 300$ м до 800 м х 1000 м. Пальне зберігається у металевих ємкостях, що встановлені групами по $8 \ldots 10$ одиниць 3 відстанню між групами $75 \ldots 100$ м.

Польовий склад боєприпасів у залежності від кількості боєприпасів, що зберігаються, займає площу від 150 м х 200 м до 1500 м х 2000 м. Боєприпаси можуть зберігатися в закритих сховищах або на відкритих обвалованих майданчиках в штабелях. Середні розміри майданчиків 15 м х 15 м. Ємкість кожного штабелю від 1 до 5 вагонів (не більше 50...60 т). Відстань між майданчиками 50...100 м.

У сучасних бойових діях об'єктами ураження авіації є розосереджені легкоуразливі цілі (до 80\% від загальної кількості цілей).

Для розрахунків представимо розосереджені цілі моделлю виду:

$$
\Omega_{\amalg}=\left\{\begin{array}{l}
\mathrm{X}_{\text {min }}^{\text {Ц }}<\mathrm{X}<\mathrm{X}_{\text {max }}^{\amalg} \\
\mathrm{Z}_{\text {min }}^{\text {Ц }}<\mathrm{Z}<\mathrm{Z}_{\text {max }}^{\amalg}
\end{array}\right.
$$

Дана модель спрощує представлення елементарних цілей, що розміщені на деякій площі для розрахунків ймовірності їх ураження [6].

У теорії авіаційного озброєння для визначення стохастичних властивостей використовується наступний підхід: уражаюча дія представляється стохастичною моделлю [6] у вигляді поверхонь рівної ймовірності, сфери, конусів, торів: 


$$
\Omega_{\text {ураження }}\left(\mathrm{W}_{\text {задане }}\right)=\left\{\begin{array}{l}
\mathrm{x}^{2}+\mathrm{y}^{2}+\mathrm{z}^{2} \leq \mathrm{R}^{2}\left(\mathrm{~W}_{\text {задане }}\right) \\
\frac{\mathrm{x}^{2}}{\mathrm{a}^{2}\left(\mathrm{~W}_{\text {задане }}\right)}+\frac{\mathrm{z}^{2}}{\mathrm{~b}^{2}\left(\mathrm{~W}_{\text {задане }}\right)}+\frac{\mathrm{y}^{2}}{\mathrm{c}^{2}\left(\mathrm{~W}_{\text {задане }}\right)} \leq 0 \\
\left(\mathrm{x}^{2}+\mathrm{y}^{2}+\mathrm{z}^{2}+\mathrm{R}_{1}^{2}\left(\mathrm{~W}_{\text {задане }}\right)\right)-4 \mathrm{R}_{2}^{2}\left(\mathrm{~W}_{\text {задане }}\right)\left(\mathrm{x}^{2}+\mathrm{y}^{2}\right) \leq 0
\end{array}\right.
$$

Тоді потрапляння точечної цілі в межах даної поверхні свідчить про ураження 3 ймовірністю вище заданої. В іншому випадку це вказує на ймовірність ураження менше заданої:

$$
W_{\text {задане }}=\left\{\begin{array}{ccc} 
& - & - \\
1 \text { якщуо } & x_{u} \in \Omega_{\text {ураження }}\left(W_{\text {задане }}\right), \text { mо } & w(\bar{x}, \bar{u}, t) \geq W_{\text {задане }} \\
0 \text { якщчо } & x_{u} \notin \Omega_{\text {ураження }}\left(W_{\text {задане }}\right), \text { то } & w(\bar{x}, \bar{u}, t)<W_{\text {задане }}
\end{array}\right.
$$

Даний методичний підхід є ефективним інструментом для досліджень стохастичних властивостей застосування АЗУ.

Відомо, що показником ефективності АЗУ $є$ ймовірність ураження наземної цілі $W_{A 3 у}$, що у загальному випадку описується формулою:

$$
W_{A 3 у}=\iiint G(x, y, z) f(x, y, z) d x d y d z,
$$

де $G(x, y, z)$ - координатний закон ураження цілі; $f(x, y, z)$ - закон розсіювання точок вибуху бойових частин (БЧ).

Закон $G(x, y, z)$ - це характеристика, що визначає вразливість цілі з одного боку, i уражаючі характеристики БЧ з іншого, і являє собою залежність ймовірності ураження цілі від координат х, у, z точки вибуху БЧ.

Закон $f(x, y, z)$ визначається характеристиками точності наведення АЗУ і точності спрацювання системи керування вибухом БЧ. Вона являє собою щільність ймовірності розподілу координат точок вибуху БЧ відносно цілі з числовими характеристиками: середньоквадратичними відхиленнями $-\sigma_{x}, \sigma_{y}, \sigma_{z}$ i математичними очікуваннями $m_{x}, m_{y}, m_{z}$.

Для спрощення подальшого розгляду питання приймемо такі припущення: ціль $є$ плоскою, площина якої лежить на земній поверхні; вибух БЧ здійснюється у площині паралельній площині поверхні цілі. 3 урахуванням цих припущень вираз (4) можна переписати у вигляді

$$
\mathrm{W}_{\mathrm{A} 3 \mathrm{y}}=\int_{-\infty}^{+\infty} \int_{0} G(x, y) f(x, y) d x d z,
$$

де $x, y$ - координати у площині земної поверхні.

Згідно з теорією бойової ефективності, уражуюча дія БЧ характеризується розмірами зони ураження $\mathrm{S}$, в середині якої ціль уражується з деякою ймовірністю $G(x, y)=G=$ const , а поза зоною ураження - не уражується, тобто $G(x, y)=0$.

Для подальших розрахунків розглянемо таку модель ураження:

- зона ураження $\mathrm{S}$ представляє собою круг з радіусом ураження $\mathrm{R}$, всередині якого ціль уражується з ймовірністю $G=1$;

- точність наведення АЗУ характеризується середніми квадратичними відхиленнями $\sigma_{x}=\sigma_{z}=\sigma$, і математичними очікуваннями $m_{x}=m_{z}=0$. 
Тоді ймовірність ураження цілі визначається як ймовірність влучення АЗУ у круг радіусом $\mathrm{R}$ :

$$
W_{A 3 y}=1-\exp \left(-\frac{R^{2}}{2 \sigma^{2}}\right)=1-\exp \left(\left(-\frac{R}{2 \sigma}\right)^{2}\right) .
$$

У якості показника ефективності штурмової авіації пропонується використати математичне очікування збитку, що характеризує уражену частину військ (об'єктів), які прикриваються угрупуваннями військ ППО та враховує ефективність застосовуваних засобів ураження авіації та ППО.

Математичне очікування величини збитків наземним об’єктам, що прикриваються угрупуваннями військ ППО, авіацією пропонується розраховувати за формулою [2]:

$$
\mathrm{M}_{\mathrm{B} 3}=\sum_{j=1}^{n} \sum_{r=1}^{R} B_{j r} g_{j r} \prod_{i=1}^{m}\left(1-P_{i j} P_{i j r}\right)^{\mathrm{X}_{i j}},
$$

де $j$ - номер літального апарату (авіації); $n$ - кількість літальних апаратів в нальоті; $r$ - номер військового підрозділу (об'єкту), що прикриваються військами ППО; $i$ - номер вогневого засобу; $m$ - кількість вогневих засобів; $P_{i j}$ - імовірність ураження $j$ - го літального апарату $i-$ м вогневим засобом; $P_{i j r}$ - імовірність того, що $j$ - й літальний апарат ввійде в зону ураження $i$ - го вогневого засобу; $X_{i j}$ - кількість цільових каналів $i$ - го вогневого засобу, що призначені $j$ - му літальному апарату; $g_{j r}$ - імовірність того, що $j$ - й літальний апарат атакує $r$ - й підрозділ (об’єкт), $B_{j r}$ - середній збиток, що може нанести $r$ - му підрозділу (об'єкту) $j$ - й літальний апарат.

Математичне очікування величини збитків наземним об'єктам, що прикриваються угрупуваннями військ ППО, авіацією можна представити у вигляді $[2,4]$ :

$$
\mathrm{M}_{\mathrm{B} 3}=\sum_{j=1}^{n} B_{j}\left[1-\sum_{i=1}^{m_{\text {цК }}} P_{i j} \mathrm{X}_{i j}\right]
$$

Математичне очікування величини збитків наземним військам (об’єктам) [2] 3 урахуванням (6) авіацією також можна представити у наступному вигляді:

$$
\mathrm{M}_{\mathrm{B} 3}=\sum_{j=1}^{n} \sum_{r=1}^{R} B_{j r} g_{j r} W_{j r \mathrm{~A} 3 \mathrm{y}}-\sum_{j=1}^{n} \sum_{r=1}^{R} B_{j r} g_{j r}\left[1-\prod_{i=1}^{m}\left(1-P_{i j} P_{i j r} W_{i r \Pi \Pi \mathrm{O}}\right)^{\mathrm{X}_{i j}}\right] .
$$

Ймовірність ураження літального апарату угрупуваннями військ ППО будемо розраховувати як $P_{j r}$ (ймовірність того, що літальний апарат не виконає завдання):

$$
1-\prod_{i=1}^{m}\left(1-P_{i j} P_{i j r} W_{i r \Pi \Pi о}\right)^{\mathrm{X}_{i j}}=P_{j r} .
$$

3 урахуванням (10) формула (9) буде мати вигляд:

$$
\mathrm{M}_{\mathrm{B} 3}=\sum_{j=1}^{n} \sum_{r=1}^{R} B_{j r} g_{j r} W_{j r \mathrm{~A} 3 \mathrm{y}}-\sum_{j=1}^{n} \sum_{r=1}^{R} B_{j r} g_{j r} P_{j r} .
$$

Таким чином, найбільш повним показником ефективності нанесення збитку наземним об’єктам, що прикриваються угрупуваннями військ ППО авіацією можна вважати математичне очікування величини збитку нанесеного авіацією об'єктам і враховує головні завдання авіації по знищенню об'єктів, ефективність застосування авіаційних засобів ураження штурмовою авіацією та важливість даних об'єктів. 


\section{Висновки}

1. Математичне очікування збитку нанесеного авіацією об'єкту, що прикривається угрупуваннями військ ППО, враховує головні завдання авіації по знищенню об'єктів, ефективність застосування авіаційних засобів ураження штурмовою авіацією та враховує важливість наземних об'єктів.

2.3 метою зменшення кількості нарядів літаків при виборі варіанту бойового завантаження необхідно враховувати характеристики авіаційних засобів ураження щодо ураження типових цілей, характеристики типових цілей, ймовірності подолання засобів протиповітряної оборони під час виходу на ціль.

3. При застосуванні літаків тактичної авіації основою для вибору типів, кількості та способів бойового застосування авіаційних засобів ураження повинні бути розрахунки ефективності удару авіацією.

\section{СПИСОК ЛІТЕРАТУРИ}

1. Срмошин М.О. Оцінка ефективності бойових дій зенітних ракетних військ: навч. посіб. / М.О. Єрмошин, Г.А. Дробаха - Х.: ХВУ, $2004-258$ с.

2. Срмошин М.О. Методичний підхід щодо визначення величини збитку, відвернутого бойовими діями угрупування військ протиповітряної оборони Сухопутних військ, військам (об’єктам), що прикриваються / М.О. Срмошин та ін. // Збірник наукових праць Харківського університету Повітряних Сил. - 2015. - №4 (35).

3. Ляшенко В. Аналіз застосування ВТЗ у ході останніх локальних конфліктів та перспективи іiі подальшого розвитку / В. Ляшенко, І. Олійник, П. Гарнець // Наука і техніка Повітряних Сил Збройних Сил України. - 2009. - № 2 (2). - С. 18-24.

4. Торопчин А.Я. Довідник 3 протиповітряної оборони / А.Я. Торопчин та ін. - К., МО України, 2003. - 366 с.

5. Кулешов О.В. Методика обгрунтування раціональної структури системи зенітного ракетно-артилерійського прикриття угрупування ППО СВ в операційному районі (зоні) / О.В. Кулешов та ін. // Збірник наукових праць Харківського університету Повітряних Сил. -2015 . - №4 (35).

6. Венцель Е.С. Исследование операцій / Е.С. Венцель - М.: Сов. радио, 1972. - 552 с.

\section{Башинський Володимир Георгійович}

доктор технічних наук, старший науковий співробітник, начальник Державного науководослідного інституту випробувань i сертифікації озброєння та військової техніки 3 випробувань, Чернігів, Україна

https://orcid.org/0000-0003-0966-5714

e-mail:dndivs@ukr.net

\section{Телевний Ігор Володимирович}

заступник начальника Державного науководослідного інституту випробувань i сертифікації озброєння та військової техніки 3 випробувань, Чернігів, Україна https://orcid.org/0000-0003-0761-3013

e-mail:niv_dndi@ukr.net

\section{Bashynskyi Volodymyr}

Doktor of Technical Sciences, Senior Researcher, Chief of State Scientific Research Institute of Armament and Military Equipment Testing and Certification, Chernihiv, Ukraine https://orcid.org/0000-0003-0966-5714 e-mail:dndivs@ukr.net

\section{Televnyi Igor}

Deputy Chief of State Scientific Research Institute of Armament and Military Equipment Testing and Certification (on Testing), Chernihiv, Ukraine https://orcid.org/0000-0003-0761-3013 e-mail:niv_dndi@ukr.net 
Збірник наукових прачь Державного науково-дослідного інституту випробувань і сертифікачії озброєння та військової техніки. 2019. Вип. № 2

\section{Нікітченко Віктор Іванович}

кандидат технічних наук, начальник науководослідного відділу Державного науководослідного інституту випробувань i сертифікації озброєння та військової техніки, Чернігів, Україна https://orcid.org/0000-0001-8973-8711 e-mail: nazar200914@gmail.com

\section{Nikitcnenko Viktor}

Candidate of Technical Sciences, Chief of Section of State Scientific Research Institute of Armament and Military Equipment Testing and Certification, Chernihiv, Ukraine https://orcid.org/0000-0001-8973-8711 e-mail: nazar200914@gmail.com

\section{METHODICAL APPROACH TO ASSESS THE LEVEL OF ENEMY LOSS CAUSED BY ASSAULT AVIATION TAKING INTO ACCOUNT EFFECTIVENES OF AIR-LAUNCHED WEAPON \\ V. Bashynskyi, I. Televnyi, V. Nikitcnenko}

The primary purpose of air attack conducted by assault aviation on ground troops (objects) is to inflict maximum damage to enemy troops (objects) which are covered by air defense force groups (air defense).

At present, group surface targets, which represent an aggregation of locally dispersed targets, are the most significant surface targets for inflicting by air-launched weapon.

During the assessment of effectiveness, the abovementioned targets can be presented as some geometrical plane on which the elementary localy dispersed targets are located. That geometric plane lies in the plane of the earth's surface.

At the same time, while doing mathematical calculations it is reasonable to take into account not all geometrical plane but only a given area. Having hit this area with a destructive element of the air-launched weapon an elementary target is considered to be destructed with a probability not less than specified one.

As a mesure of assault aviation effictiveness it is suggested to use the mathematical expectation of the extent of loss caused to surface targets (objects) covered by air defense forces, also taking into account the effectiveness of the use of air-launched weapon by assault aviation, the main objectives of aviation on the destruction of objects, and the importance of these objects.

In order to reduce the number of aircraft detachments when choosing a combat loading option, it is necessary to take into account the characteristics of air-launched weapon against the defeat of typical targets, the characteristics of typical targets, the probability of overcoming the air defence means during inflightt.

Keywords: lethal hit probability, extent of loss, typical targets, assault aviation. 